\title{
Vellore - A Hub For Medical Tourism
}

\author{
N.Md Faiyaz Ahmed \\ M.Com, M.Phil, NET, Assistant Professor, \\ Commerce (Finance \& Accounts) \\ Islamiah College (Autonomous), Vaniyambadi, Tamil Nadu, India
}

\section{INTRODUCTION}

Medical tourism or health tourism is a term initially refers to the act of patient going to different country for either urgent or medical procedure or patient travelling from one place to another for specialized surgical and other forms of specialized treatment. It is perceived as one of the fastest growing and emerged as the most promising industry in most of the countries including India.

India has emerged as one of the leader in promoting medical tourism. The Indian medical tourism industry growing at an amount of $30 \%$ patients from Europe, west Asia, U.S and Africa. An estimate of 15000 patients arrived from across the globe from U.S.A, U.K, Middle East, Africa and SAARC countries for medical treatment in India.

Indian corporate hospitals have a large pool of doctors, nurses and supporting staff ensuring individual care. The highly skilled personnel with wide experience and international exposure excel in cardiology, orthopedic surgery, dentistry and dermatology. To name a few Apollo Hospital group, MIOT Hospital -Chennai, Manipal Hospital Group Bangalore are some of the well known hospital for medical tourism.

\section{Why India:}

1) The medical expenses in India are one- tenth of the cost in western countries.

2) India offer the best treatment in modern medicine

3) Fluent English speaking staff.
4) Highly qualified physician/ surgeons

5) Many foreign patient prefer to combine leisure and relaxation visits to India

6) India has diverse tourist locations

7) Provide alternative medication like Ayurveda, Pranic healing, Aroma therapy, Herbal and yoga.

\section{Medical Tourism in Tamilnadu:}

Tamilnadu is one such state which is famous for the Medical Tourism, There are several world class facilities equipped with the latest testing facilities available. One can come to Tamilnadu for a specific treatment or even go for a mental health check up while on holiday. Tamilnadu is famous for the treatment of cardiac care, Transplant, Eye care and cosmetic surgery. Apart from allopathic treatment Tamilnadu is famous for Ayurveda, Siddha, Unani, Homeopathy, Acupuncture, healing and Reiki. Tamilnadu has many famous hospitals like Apollo Hospital at Chennai and Madurai, Madras Medical Mission, Miot Hospitals and Shankara Netralya at Chennai, Arvind Hospitals at Madurai and Coimbatore, PSG Hospital at Coimbatore and CMC Hospital in Vellore. The state government is also aggressively promoting Medical/ Health Tourism. It is a much more peaceful state than any other state in south India. 


\section{Scope of the Study:}

Vellore which is situated 145 K.m from the capital city of Tamilnadu Chennai, is a semi rural bazaar town which is expanding with the setting up of commercial, administrative and medical centres. An ancient town, Vellore was the seat of the valiant pallavas, cholas, Nayak, Maratha, Arcot nawab and Bijapur sultans' kingdoms. Vellore district lies between $12^{\circ} 15^{\prime}$ to $13^{\circ} 15^{\prime}$ North latitudes and $78^{\circ}$ $20^{\prime}$ to $79^{\circ} 50^{\prime}$ East longitudes in Tamilnadu State.

The geographical area of this district is 6077 sq. k.m. Vellore is the Head-Quarters of Vellore District and is well connected by Rail and bus routes to major towns of the neighbouring states like Andhra Pradesh, Karnataka and Kerala.

\section{Significance of the Study:}

\section{Allopathy Medicine}

Christian medical college \& Hospital (CMC) one of the largest hospitals in India is located in the heart of Vellore. It attracts a floating population of at least 5000 person a day from across India and foreign countries. The hospital was founded in the early part of the $20^{\text {th }}$ century by an American medical missionary Dr, Ida S. Scudder. It also occupies a prominent place among medical institution in India. The CMC Hospital has a functioning quality management programme and is one of the first Asian Hospital to have been awarded the ISO Certificate. The mental health centre and Rehabilitation centre in the college campus, the base hospital at CHAD and RUHSA and the Ida Scudder ward and eye hospital in the Schell campus. The services range from internal medicine and child health to neurology and neurosurgery, organ transplantation, advanced cardiology and other complicated surgical treatment are done here. Apart from the quality treatment it has good tourism places and there are a number of luxury hotel are available near the hospital like Hotel Aavanaa Inn, Hotel Palm Tree, Hotel Darling Residency etc.

Another famous hospital for allopathic treatment in Vellore district is the Apollo KH Hospital; Ranipet was established on the $14^{\text {th }}$ September, 2003. It is an association between Apollo Hospital Enterprise Ltd and the K.H Group. The hospital campus is spread across 10 acres of land. The 100-bed multi specialty hospital was founded with the objective of rural upliftment and development of community health.
The hospital reserves a special focus for the healthcare of women and children. It's famous for general surgery, obstetrics, gynecology, cardiology, ENT, Neurology, Urology, Dermatology and infertility clinic. It is situated on the ChennaiBangalore Highway. Patients are coming from Bangalore, Chennai, Kanchipuram, and in and around the Vellore district.

Bethesda Hospital is situated in Ambur town, with a population of more than one lakh and is surrounded by approximately 60 villages and hamlets. The hospital with a campus area of 35 acres serves the health need of very large segment of the rural populations. Patients come from the nearby larger towns such as Vaniyambadi, Pernambut, Gudiyattam, Jolarpet, Nattrampalli and Tirupattur and also from Districts like Salem, Dharmapuri and Kuppam. It is famous for orthopedic surgery, Radiology, Dentistry, Pediatrics and other Emergency services etc

Tirupattur is a town located in Vellore District, Tamil Nadu, and India. It is located approximately $35 \mathrm{~km}$ from Krishnagiri and $80 \mathrm{~km}$ from Hosur. It's famous for the medical treatment of eye care. Specialist Eye care surgeon are running their own dispensary.

\section{SIDDHA MEDICINE}

Walajapet which is famous for Siddha medicine is a locality and part of Vellore city in the state of Tamil Nadu. It is strategically located on the Palar River on the route between Chennai (Madras) and Bangalore. By bus, this locality can be reached in about 30 minutes from Vellore city center and in about 2.5 hours from Chennai. It is well connected both by road and railways. Walajah Road railway station is located about $4.5 \mathrm{~km}$ from the town, lying between Arakkonam and Katpadi junctions on the important railway route connecting Chennai to Coimbatore and Bangalore. It was the station connecting Arakonam and Katpadi, the first rail route in Tamilnadu. Their system is capable for treating all types of disease other than emergency cases; in general it is effective in treating any types of skin problems. It is effective for paralysis and effectively heals wound, cuts and burns. Numbers of private dispensaries are running by the expert practitioners in this field around walajapet. 


\section{UNANI MEDICINE}

Dr. Akbar Kouser popularly known as "Bade Hakeem Saheb" one of the renowned god gifted miracle man who is famous all over India, who established a foundation in 1971 in Vaniyambadi (65 K.m from Vellore) and made unique herbal medicines which cure every disease without any surgical operations approved by world renowned doctors. The medicine can cure Kidney Diseases, Cancer, Diabetes, Joint Pain, Liver, Skin Diseases, Asthma problems, Rehabilitation and many other incurable diseases. Number of patient from across India and also foreign patient are come for treatment at regular intervals.

This man proved that every disease can be cured with natural herbs. He has own Mughal garden in which he is farming herbs under his guideline. $\mathrm{He}$ is institutionally qualified in Herbal Medicine, Medicinal plants, Aromatic Plants, Chinese Medicine, Yoga, Naturopathy, Oil theraphy, Beauty and Aroma therapy. Dr. Akbar Kausar's Hospital Complex consisting of the AI-Kausar Unani International Hospitals, Daiveega Maruthuvam Unani Hospital, Al Kausar Unani Kidney Foundation, Al Kausar Unani Liver Foundation, Colour therapy, Magnetotherapy, Chinese Acupuncture centre, Alcohol and Drug Deaddiction and Rehabilitation centre, Publication Department, Research section, Pharmacy block, and the Herbal farm. He is an experienced and expert physician in Prophet's medicine, Arabian herbal treatment, Unani Medicines, Chinese Acupuncture and Homoeopathy. With his vast medical experience, he has written more than 300 medical books. Five of his medical books are included in the syllabus of Madurai Kamraj University .His books are published in English, Tamil, Urdu, Malayalam, Kannad and telegu.

Another most important place for Unani medical treatment is in pernambut. This is 34 K.m from Vaniyambadi. This panchayat town is famous for hakims. Most of the patients are visiting the town for medical treatment from Vaniyambadi, Ambur, Vellore, Gudiyatam, Tirupattur and also from other states and sometimes patients from foreign countries.

\section{CONCLUSION}

Indian, NRIs and tourist from around the world are beginning to realize the potential of modern and traditional Indian medicine followed in Vellore district. The hospitals in and around Vellore also realized of this niche market and have begun to tailor their services for outside patient. But it also required the co operation of the state government to make the effort to promote the medical tourism in Vellore district.

\section{Bibliography:}

1. Bezbaruah, "Indian Tourism Industry", Gya publishing House, New Delhi,1999.

2. Bhatia.A.k, "Tourism Management and Marketing",Sterling Publishers Private Ltd, New Delhi,1997.

3. Thompson Neil "Medical Tourism",Motilal banarsidas publishers Pvt Ltd, New Delhi,2011.

4. Chopra,Subitha, "Tourism and Development in Indai",Ashish Publishing House, New Delhi, 1994

5. www.Cmc-vellore.edu

6. www.Herbalhospitals.com

7. www.apollokh.com 